\title{
Deformation of footwall rock of Phulad Shear Zone, Rajasthan: Evidence of transpressional shear zone
}

\author{
Manideepa Roy Choudhury, Subhrajyoti Das, \\ Sadhana M ChatterueE* and Sudipta Sengupta \\ Department of Geological Sciences, Jadavpur University, Kolkata 700 032, India. \\ ${ }^{*}$ Corresponding author.e-mail: smcjugeo@gmail.com
}

Phulad Shear Zone (PSZ) of Delhi Fold Belt in Rajasthan is a northeasterly striking ductile shear zone with a well developed mylonitic foliation $(035 / 70 \mathrm{E})$ and a downdip stretching lineation. The deformation in the PSZ has developed in a transpressional regime with thrusting sense of movement. The northeastern unit, i.e., the hanging wall contains a variety of rocks namely calc-silicates, pelites and amphibolites and the southwestern unit, i.e., the footwall unit contains only granitic rocks. Systematic investigation of the granites of the southwestern unit indicate a gradual change in the intensity of deformation from a distance of about $1 \mathrm{~km}$ west of the shear zone to the shear zone proper. The granite changes from weakly deformed granite to a mylonite/ultramylonite as we proceed towards the PSZ. The weakly deformed granite shows a crude foliation with the same attitude of mylonitic foliation of the PSZ. Microscopic study reveals the incipient development of $\mathrm{C}$ and $\mathrm{S}$ fabric with angle between $\mathrm{C}$ and $\mathrm{S}$ varying from $15^{\circ}$ to $24^{\circ}$. The small angle between the $\mathrm{C}$ and $\mathrm{S}$ fabric in the least deformed granite variety indicates that the deformation has strong pure shear component. At a distance of about $1 \mathrm{~m}$ away from the PSZ, there is abrupt change in the intensity of deformation. The granite becomes intensely foliated with a strong downdip lineation and the rock becomes a true mylonite. In mesoscopic scale, the granite shows stretched porphyroclasts in both XZ and YZ sections indicating a flattening type of deformation. The angle between the $\mathrm{C}$ and $\mathrm{S}$ fabric is further reduced and finally becomes nearly parallel. In most places, $\mathrm{S}$ fabric is gradually replaced by $\mathrm{C}$ fabric. Calculation of sectional kinematic vorticity number $\left(W_{\mathrm{n}}\right)$ from the protomylonitic and mylonite/ultramylonite granites varies from $0.3 \pm 0.03$ to $0.55 \pm 0.04$ indicating a strong component of pure shear. The similarity of the geometry of structures in the PSZ and the granites demonstrates that the deformation of the two units is broadly synchronous and the deformation in both the units is transpressional.

\section{Introduction}

The Phulad Shear Zone (PSZ) (figure 1) of Rajasthan is a long narrow zone of intense deformation, running in a northeasterly direction for several kilometers and demarcates the western margin of the Proterozoic Delhi Fold Belt (Heron 1953; Sychanthavong and Desai 1977; Gupta et al. 1980; Sen 1980; Sinha Roy 1988; Sinha Roy et al. 1993; Gupta et al. 1997; Golani et al. 1998; Ghosh et al. 1999). The PSZ is characterized by extensive mylonitization with a thrusting sense of movement (Sengupta and Ghosh 2004). The average attitude of the mylonitic foliation is $035 / 70 \mathrm{E}$ with subvertical lineation. Detailed structural studies of the PSZ by Sengupta and Ghosh (2004, 2007) indicate that the deformation in the shear zone is transpressional, i.e., in addition to the simple shear there is a component of pure shear across the shear zone. The strain of PSZ mainly concentrates along the

Keywords. Phulad Shear Zone; transpressional; footwall deformation; Proterozoic; Rajasthan. 


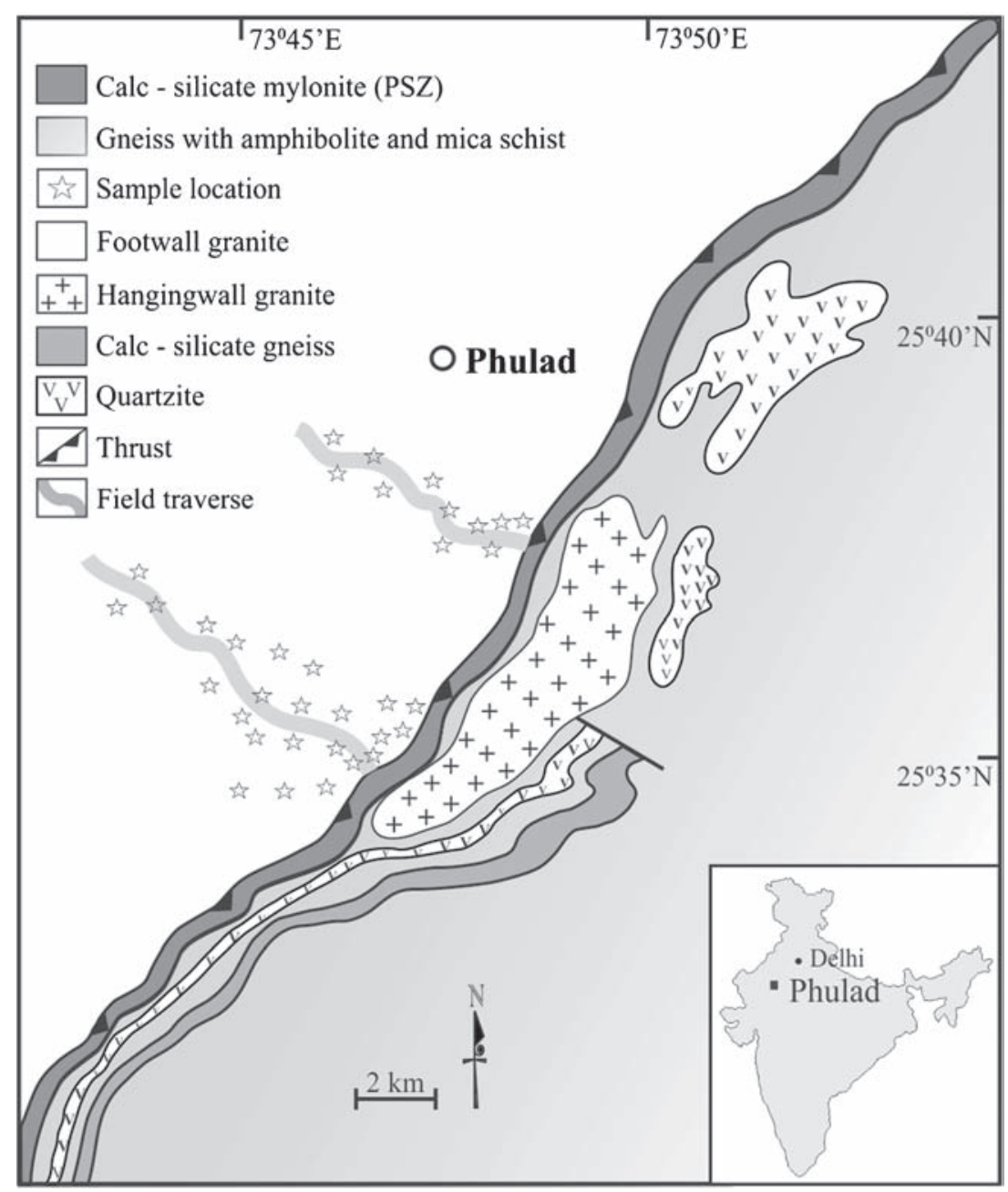

Figure 1. Simplified geological map of the study area modified after Ghosh et al. (1999).

bands of interlayered calcareous and quartzofeldspathic mylonites. The PSZ lies between two different lithounits. The northeastern unit contains a variety of rocks, viz., calc-silicates, pelites and amphibolites and the southwestern unit contains only granitic rocks. The relationship of these southwestern granites with the PSZ is not clear (Heron 1953; Gupta et al. 1980, 1997; Sinha-Roy 1988), i.e., whether the granites acted as footwall for the PSZ or emplaced after the deformation of the PSZ. Moreover, there is dearth of information about the deformation pattern of the granites of the southwestern unit. To know whether these granites were really/never part of the PSZ, a systematic study along two transects across the granite was carried out to examine the state of deformation.

\section{Mesoscopic structures in granite}

The granitic rocks to the southwestern side of the PSZ show prominent development of foliation and lineation that are parallel to the mylonitic foliation of the PSZ. At a distance of about $1 \mathrm{~km}$ away from the PSZ, the granites are coarse grained with some of the feldspar grains varying in size from 3 to $4 \mathrm{~cm}$ (figure 2a). The rock shows a crude foliation with barely visible downdip lineation. As we move towards the shear zone the granites gradually become well foliated with strong development of lineation. There is also gradual grain size reduction towards the PSZ. At a distance of about $500 \mathrm{~m}$ from the PSZ, the rock becomes finer grained with very well developed foliation and a strong downdip stretching lineation (figure $2 \mathrm{~b}$ ) indicating thereby further increase in the intensity of deformation. Close to the PSZ, there is an abrupt change in the intensity of deformation in the granite (figure 2c). The rock becomes a true mylonite with very strong foliation and downdip lineation. In both XZ section (perpendicular to the foliation and parallel to the downdip lineation) and YZ section (perpendicular to the foliation and downdip lineation), the granite shows stretched grains (figure $3 \mathrm{a}, \mathrm{b}$ ). The aspect ratio of the stretched grains in $\mathrm{XZ}$ section varies 

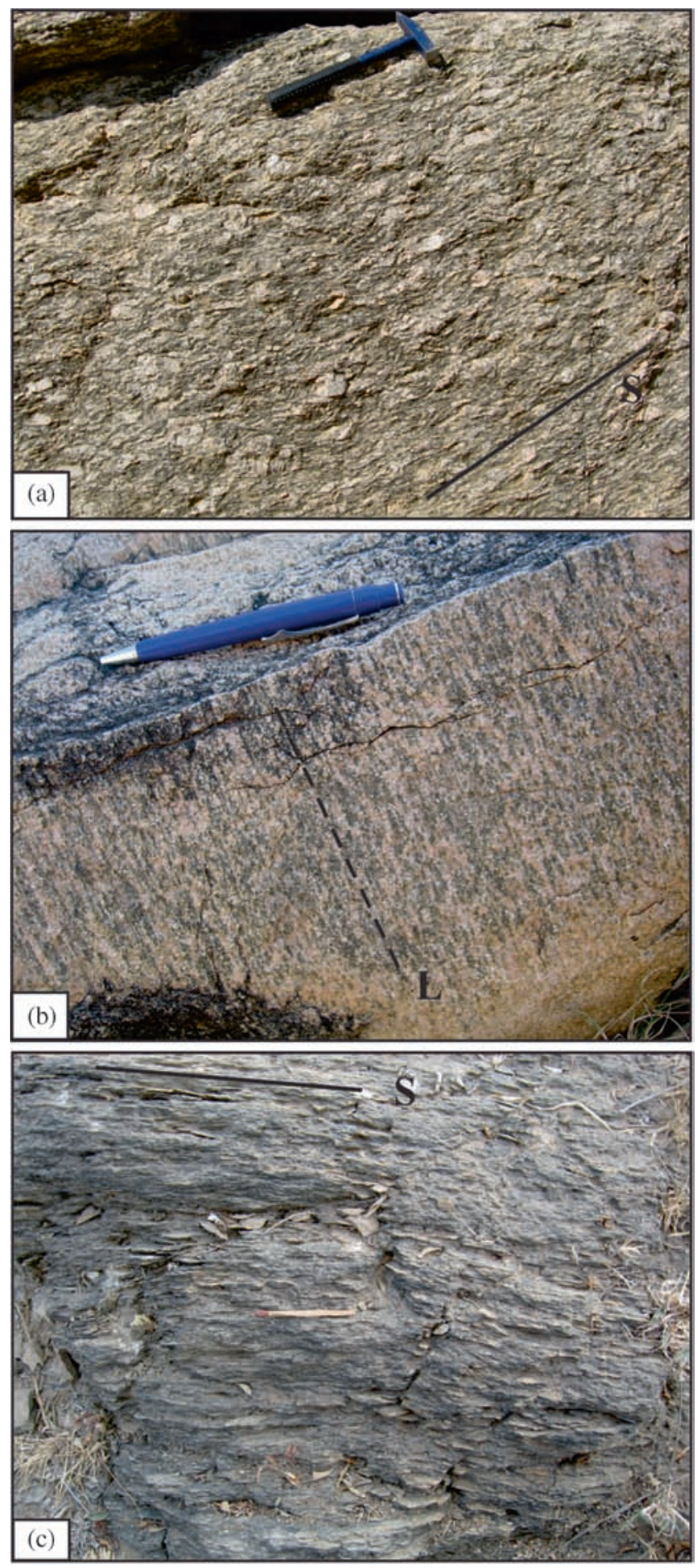

Figure 2. (a) Field photograph of weakly deformed coarse grained granite at a distance of $1 \mathrm{~km}$ from the proper shear zone. The bold line shows the trace of foliation in the granite. Note the presence of large feldspar clasts. (b) Field photograph of profile section of the granite showing the strong downdip stretching lineation (marked by broken line). (c) Field photograph of mylonitic granite close to the shear zone. The length of the match stick in (c) is $5 \mathrm{~cm}$.

from 1.5 to 3.8 and in YZ section varies from 1.2 to 2.25 (figure $3 \mathrm{c}$ ) indicating a flattening type of deformation.

\section{Microstructural variation of the granite}

The granitic rock, southwestern unit of the PSZ, is mainly consists of quartz, feldspar (plagioclase and K-feldspar) and biotite. On the basis of their intensity of deformation, i.e., fabric development, grain size reduction and degree of recrystallization the granite is divided into three longitudinal divisions, e.g., (1) weakly deformed granite, (2) protomylonites, and (3) mylonites and ultramylonites.

\subsection{Weakly deformed granite}

At a distance of about $1 \mathrm{~km}$ away from the shear zone the granitic rocks are categorized as weakly deformed granite. These weakly deformed granites show a crude foliation defined by broad parallelism of biotite flakes and weak shape preferred orientation of quartz-feldspar aggregates. These granites contain large porphyroclasts of feldspar within a matrix (10-20\%) of fine-to-medium grained assemblage of quartz, feldspar and biotite. Feldspar grains show strong undulose extinction with curved grain boundaries, kink and bent twin lamellae. Bulging grain boundaries, subgrains and grain refinement indicate dynamic recrystallization (figure $4 \mathrm{a}-\mathrm{c}$ ). Feldspar grains with brittle fractures are also common. At places small recrystallized grains of quartz are present along fractures of the feldspar porphyroclasts (figure 4a). Polygonized quartz grains with development of triple junction mainly occur in the matrix (figure 4d). Few isolated flattened quartz with strong undulose extinction are also present mainly wrapping large feldspar grain.

\subsection{Protomylonites}

As we move towards the PSZ, the rock becomes more strained with decreasing number of porphyroclasts. The percentage of recrystallized matrix varies between 20 and 50\%. Feldspar megacrysts show irregular grain boundaries with strong undulose extinction. Polygonized quartz grains with triple junction at grain boundaries are preserved only in the lensoidal aggregates (figure 5a). However, quartz grains are mainly stretched to form polycrystalline ribbon structure. Quartz grains within the ribbon structure show irregular grain boundaries with undulose extinction. Quartz ribbon also warps around large feldspar grains (figure 5b). Matrix quartz grains show irregular grain boundaries. Isolated quartz megacrysts with strong undulose extinction are stretched parallel to the foliation. Protomylonites show incipient development of $\mathrm{C}-\mathrm{S}$ fabric where $\mathrm{C}$ denotes the shear plane and $\mathrm{S}$ denotes the plane containing the 


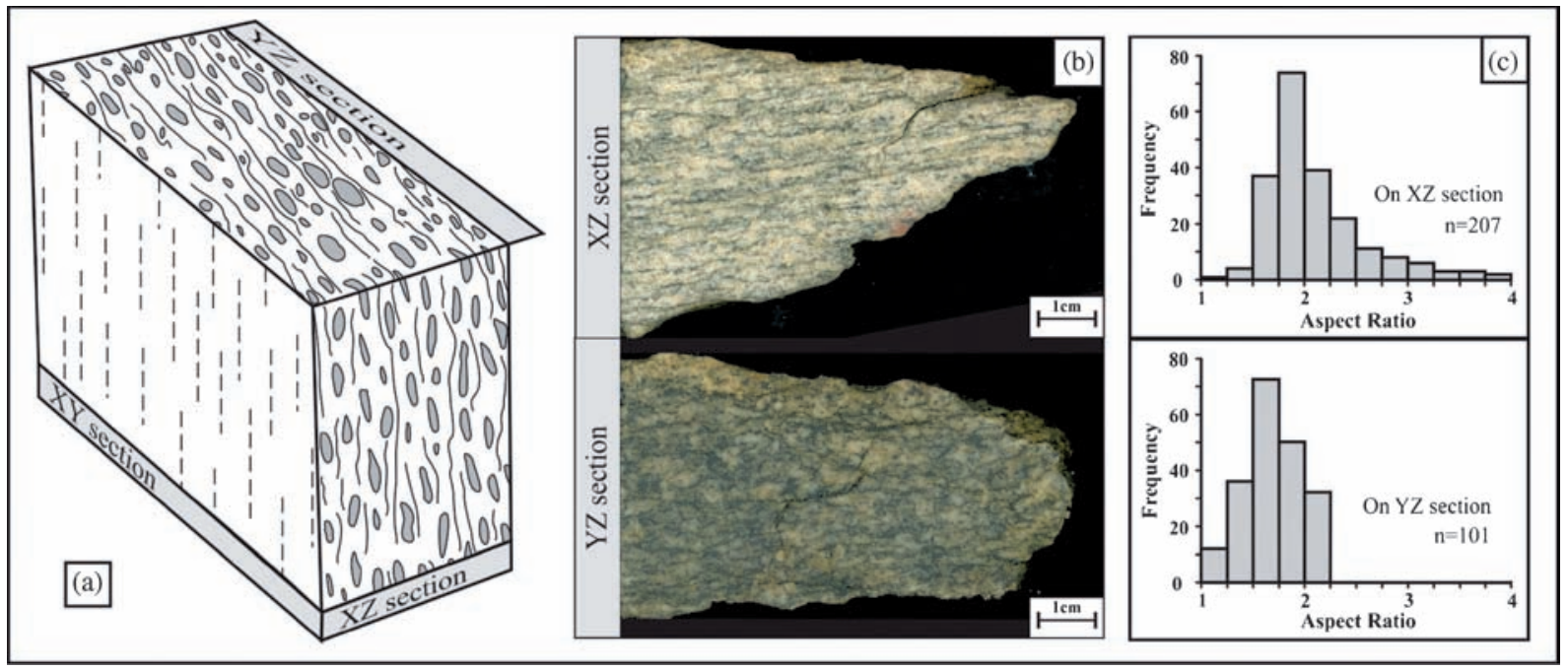

Figure 3. (a) Block diagram showing the XZ (perpendicular to the foliation and parallel to the lineation), YZ (perpendicular to the foliation and lineation) and XY (parallel to the foliation and lineation) sections. (b) Hand specimen photograph showing the stretched porphyroclasts in both XZ and YZ sections. (c) Histogram showing the distribution of aspect ratio of stretched porphyroclasts in XZ and YZ sections. Note the aspect ratio in XZ is greater than YZ section. ' $\mathrm{n}$ ' denotes the number of data.
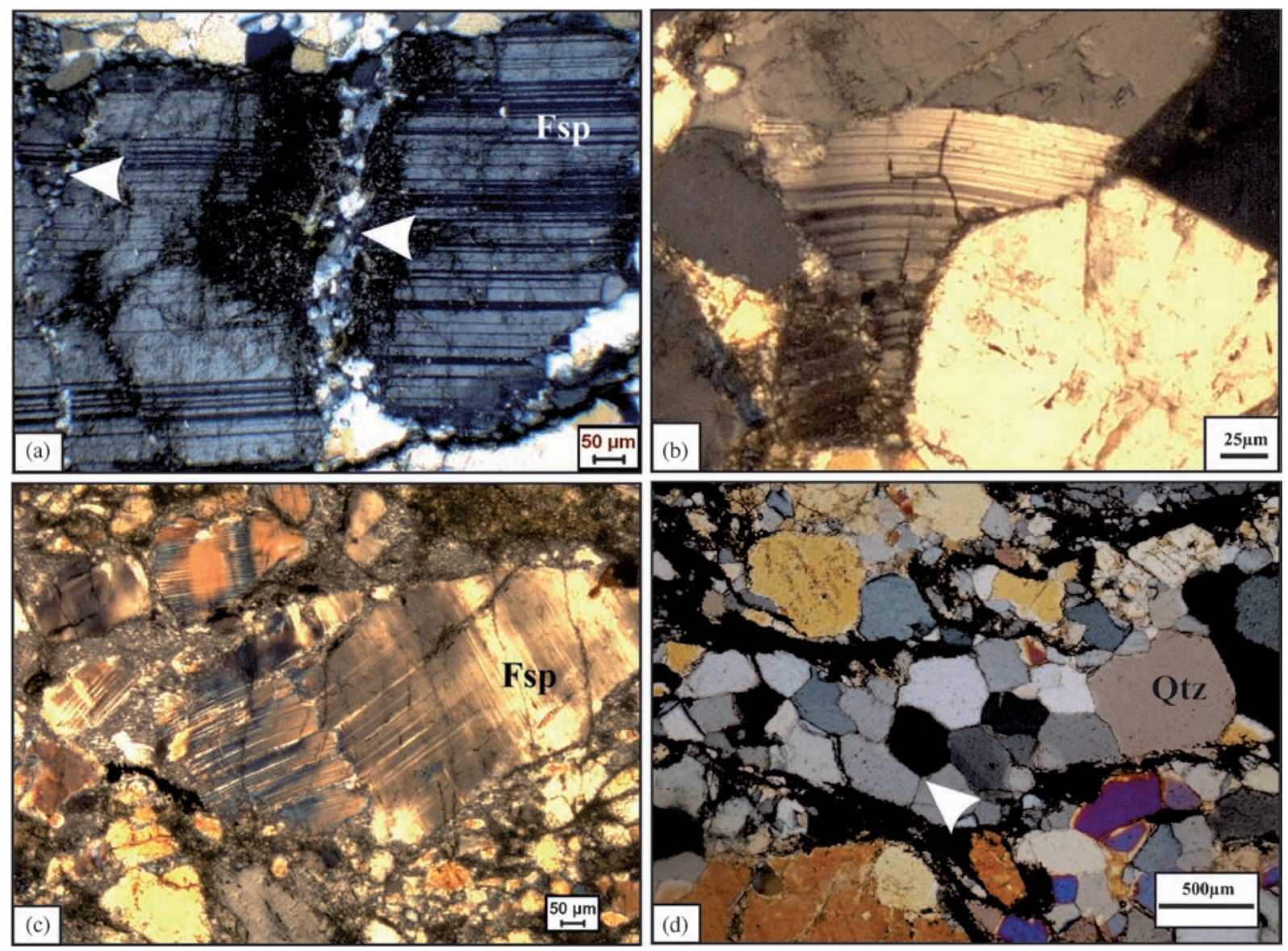

Figure 4. (a) The photomicrograph shows the presence of quartz grains along the fracture of the feldspar grain (marked by arrow head). (b) Feldspar grain showing bent twin lamellae. (c) Feldspar grain showing kink. (d) Recrystallized quartz in the matrix shows dominant grain refinement. Quartz grain triple junction is shown by arrow head. Photomicrographs (a-d) are in cross polarized light. 

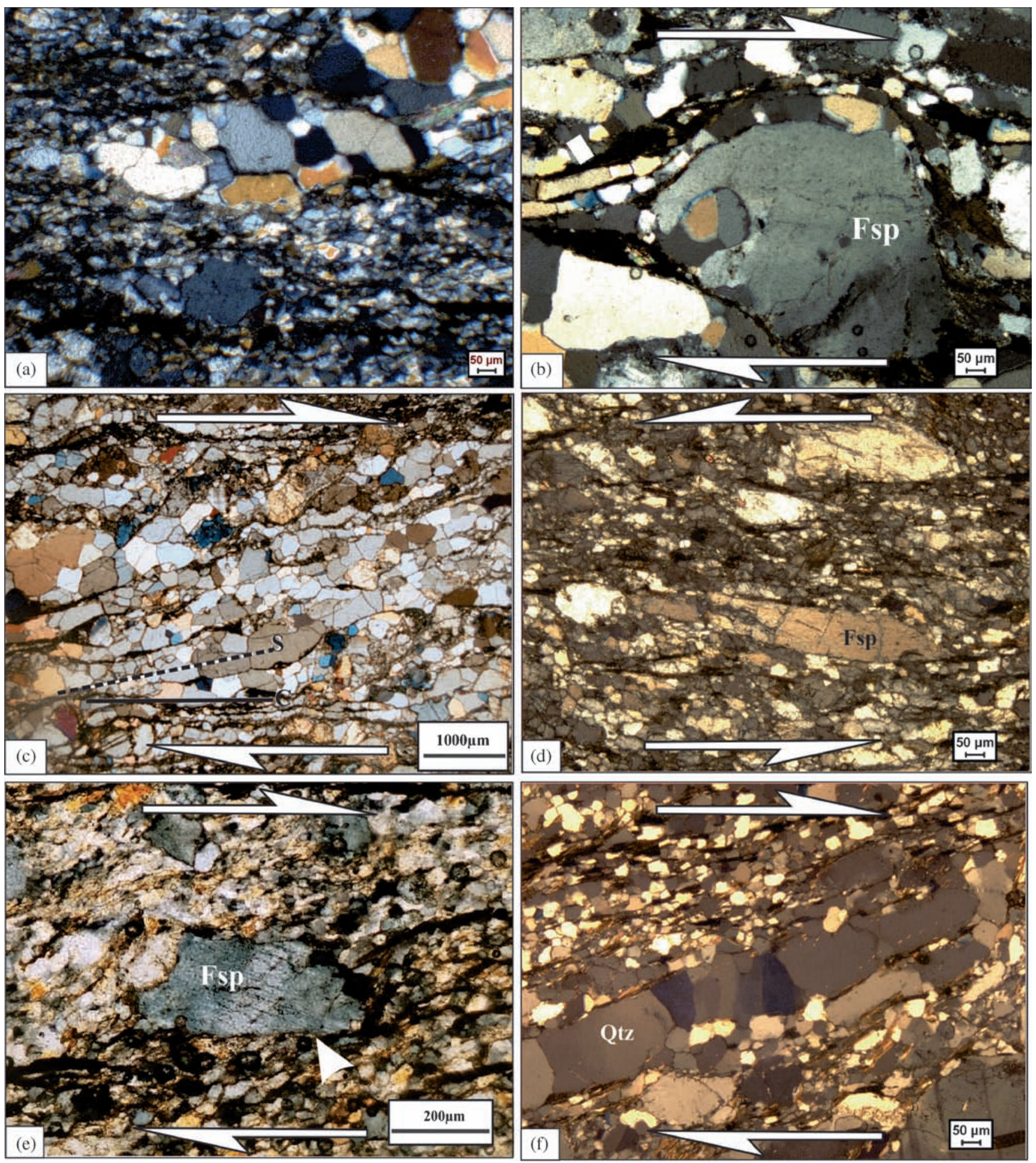

Figure 5. (a) Aggregates of polygonized quartz grains with triple junction are preserved in lensoidal forms. (b) Incipient development of polycrystalline quartz ribbon with curved boundary wrapping around the feldspar porphyroclast. (c) Photomicrograph showing C-S fabric. Angle between C (Black line) and S (Black broken line) is $12^{\circ}$. (d) Photomicrograph showing the stretched feldspar grain aligned parallel to the mylonitic foliation. (e) Feldspar porphyroclast (centre) showing irregular grain boundary and undulose extinction. (f) Mylonite showing well developed polycrystalline quartz ribbon with quartz subgrain formation. Photomicrographs $(\mathbf{a}-\mathbf{f})$ are in cross polarized light. White arrows with black border in photomicrographs (b-f) indicate the general sense of shearing.

maximum and intermediate axes of strain. The Cfabric is demarcated by biotite and recrystallized subgrains of quartz, whereas the S-fabric is mainly defined by quartz subgrains with few biotite. The angle between $\mathrm{C}$ and $\mathrm{S}\left(\mathrm{C}^{\wedge} \mathrm{S}\right)$ varies between $20^{\circ}$ and $24^{\circ}$. This angle between $\mathrm{C}$ and $\mathrm{S}$ further 
reduces gradually as we move towards the PSZ (figures 5c,6).

\subsection{Mylonites and ultramylonites}

At the contact of PSZ, there is a sharp increase in the degree of recrystallization and the rock

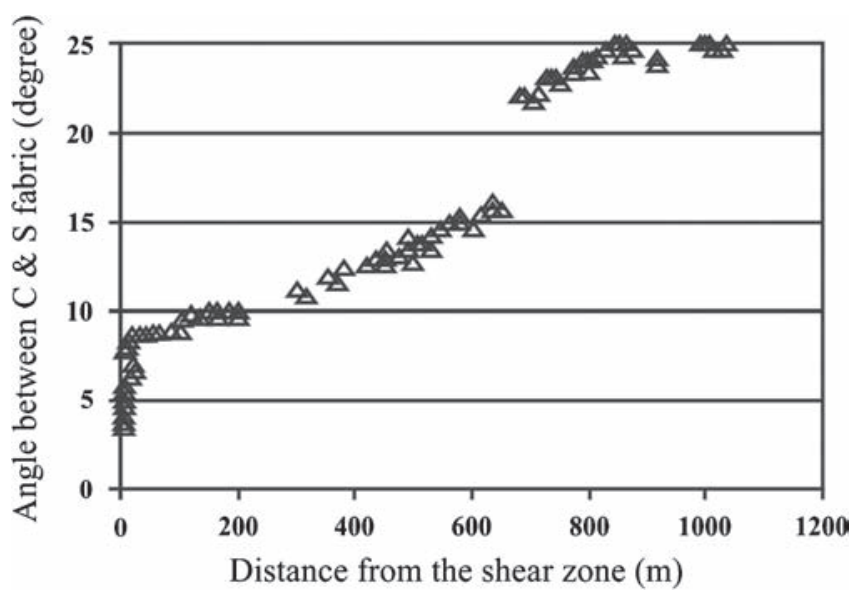

Figure 6. Graphical representation of the change of angle between $\mathrm{C}$ and $\mathrm{S}$ with increasing distance from the PSZ. becomes a mylonite and with further reduction of porphyroclasts, transformed to an ultramylonite. Most of the feldspar grains are stretched parallel to the mylonitic foliation (figure $5 \mathrm{~d}$ ). Few feldspar grains show strong undulose extinction with irregular grain boundaries (figure 5e) depicting grain boundary migration recrystallization (Vernon 2004; Passchier and Trouw 2005). Quartz mainly occurs as bands forming ribbon structure with curved grain boundaries (figure 5f). Formation of quartz subgrain within the ribbon structure is also common. The angle between $\mathrm{C}$ and $\mathrm{S}$ fabric is further reduced and $\mathrm{S}$ is gradually replaced by $\mathrm{C}$. Figure 6 shows the variation of $\mathrm{C}^{\wedge} \mathrm{S}$ with increasing distance from the PSZ.

\section{Kinematic vorticity analysis}

The measure of the degree of instantaneous noncoaxiality of a flow is represented by the kinematic vorticity number, $W_{k}$. There are several methods to obtain the kinematic vorticity number. For the convenience of our work we chose Oblique grain-shape foliations of recrystallized quartz aggregate to calculate the sectional kinematic vorticity number,

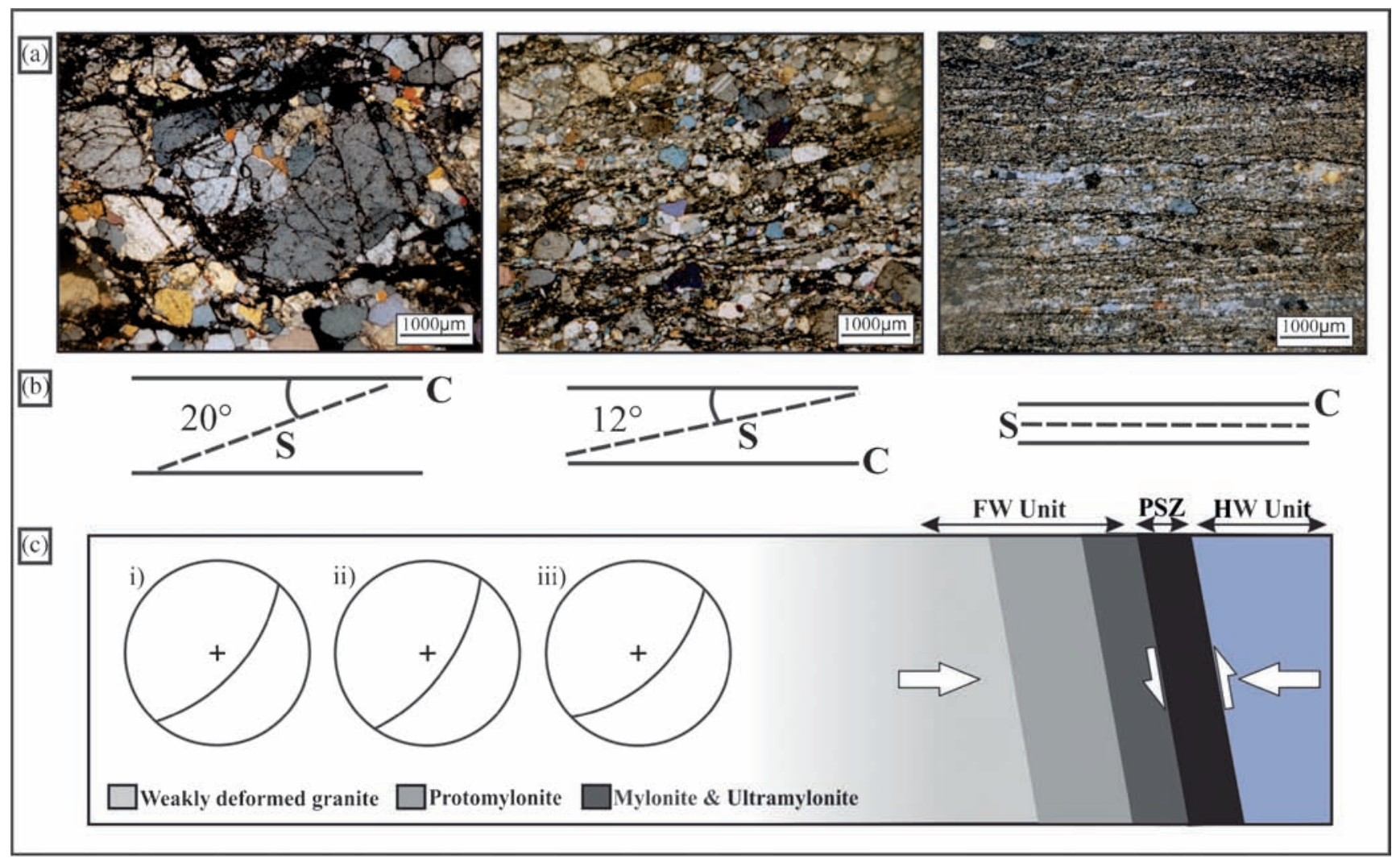

Figure 7. (a) Summary diagram showing the systematic change of granite grain size as we move towards the PSZ. (b) Schematic representation showing the angle between C-S decreases towards the PSZ. (c) Schematic profile section showing distribution of weakly deformed granite, protomylonite, mylonite and ultramylonite and the orientation of respective mesoscopic fabrics are shown in insets. Sketch not to scale. 
$W_{n}$ (as it is a monoclinic flow) value. According to Wallis (1995), the orientation of the long axes of quartz neoblasts within an oblique foliation delin-

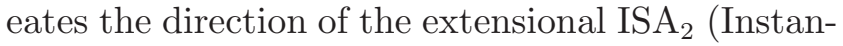
taneous Stretching Axes). Experimental studies (Dell'Angelo and Tullis 1989; Ree 1991; Herwegh and Handy 1998) also support this assumption, which showed that during progressive deformation oblique grain-shape fabrics nucleate with their long axes in a fixed orientation with respect to the imposed kinematic reference frame. We can obtain the sectional kinematic vorticity number, $W_{n}$ by using the equation $W_{n}=\sin 2 \xi$ (Weijermars 1991) where $\xi$ is the greatest angle between the oblique foliation $\left(\mathrm{ISA}_{2}\right.$ ) and the flow apophysis $\mathrm{A}_{2}$ (Xypolias 2010). In our study area we calculated this $W_{n}$ value for the granitic rocks on $\mathrm{XZ}$ section, i.e., the plane perpendicular to the foliation (XY) and parallel to the lineation $(\mathrm{X})$. In the protomylonitic variety of granites, the angle $\xi$ varies from $7^{\circ}$ to $10^{\circ}$ with $W_{n}$ value varying from 0.24 to 0.34 with an average of $0.3 \pm 0.03$. For mylonite and ultramylonite variety, the $\xi$ angle varies from $15^{\circ}$ to $18^{\circ}$ and the $W_{n}$ value varies from 0.5 to 0.59 with an average of $0.55 \pm 0.04$. $W_{n}$ value for weakly deformed granite could not be measured using this method as the quartz aggregate of this granite does not show any distinct oblique grain shape. The calculated $W_{n}$ values for the granitic rocks falls in the pure shear dominated transpression regime (Fossen and Tikoff 1993).

\section{Discussion and conclusion}

During ductile deformation of any shear zones, the rocks of the footwall side may remain rigid or may suffer deformation along with the shear zone with similar geometry of structures (Ramsay and Huber 1983; Daniel et al. 1996; Gutikrrez-Alonso 1996; Singh and Thakur 2001; Tripathy et al. 2009; Fossen 2010). The wall rocks generally remain undeformed where the deformation in the shear zone is by simple shear only. However, if the strain deviates from simple shear, the wall rocks may get deformed (Simpson and De Paor 1997, p. 171).

The present investigation indicates a gradual change in the intensity of deformation in the granites that lies southwestern part of the PSZ from a distance of about $1 \mathrm{~km}$ west to the shear zone proper (figure 7). The granite changes from weakly deformed to a mylonite as we proceed towards the PSZ with attitude of foliation parallel to the mylonitic foliation of the shear zone. The weakly deformed granite also shows a crude foliation with the same attitude of mylonitic foliation. There is incipient development of $\mathrm{C}$ and $\mathrm{S}$ fabric with $\mathrm{C}^{\wedge} \mathrm{S}$ varying from $24^{\circ}$ to $15^{\circ}$. The small angle between the $\mathrm{C}$ and $\mathrm{S}$ fabric in the least deformed variety indicates that the bulk deformation is transpressional. As we move towards the shear zone, the rock becomes more deformed with further decrease in the angle between $\mathrm{C}$ and $\mathrm{S}$. At a distance of about a meter from the proper shear zone, the granite becomes mylonite to ultramylonite. The angle between $\mathrm{C}$ and $\mathrm{S}$ is greatly reduced and $\mathrm{S}$ is replaced by $\mathrm{C}$. Presence of stretched grains in both $\mathrm{XZ}$ and $\mathrm{YZ}$ sections in granites also indicate a three dimensional strain with a component of flattening across the shear zone. Kinematic vorticity analysis from the different parts of granites revealed that the deformation has occurred in pure shear dominated transpressional regime. Presence of deformed wall rocks also indicates that the bulk strain in the PSZ is not by simple shear alone (Simpson and De Paor 1997). The similarity of the geometry of structures in the PSZ and the granites indicates that the deformation of the two units is broadly synchronous and the bulk strain in both the units is transpressional.

\section{Acknowledgements}

SMC acknowledges Department of Science and Technology, New Delhi (India) for funding the FAST TRACK research project. SS and SMC acknowledge the Council of Scientific and Industrial Research grant.

\section{References}

Daniel J M, Jolivet L, Goffe B and Poinssot C 1996 Crustalscale strain partitioning: Footwall deformation below the Alpine Oligo-Miocene detachment of Corsica; J. Struct. Geol. 18 41-59.

Dell'Angelo L N and Tullis J 1989 Fabric development in experimentally sheared quartzites; Tectonophys. 169 $1-21$.

Fossen H 2010 Structural Geology; Cambridge University Press, UK, 457p.

Fossen H and Tikoff B 1993 The deformation matrix for simultaneous simple shearing, pure shearing and volume change, and its application to transpression-transtension tectonics; J. Struct. Geol. 15 413-422.

Ghosh S K, Hazra S and Sengupta S 1999 Planar, non-planar and refolded sheath folds in Phulad shear zone, Rajasthan, India; J. Struct. Geol. 21 17151729 .

Golani P R, Reddy A B and Bhattacharjee J 1998 The Phulad Shear Zone in Central Rajasthan and its Tectonostratigraphic implications; In: The Indian Precambrian (ed.) Paliwal B S, Scientific Publishers (India), Jodhpur, pp. $272-278$.

Gupta S N, Arora Y K, Mathur R K, Iqbaluddin, Prasad B, Sahai T N and Sharma S B 1980 Lithostratigraphic map of the Aravalli region, southern Rajasthan and northeastern Gujarat: Scale 6441:1000000; Geological Survey of India, Calcutta. 
Gupta S N, Arora Y K, Mathur R K, Iqbaluddin, Prasad B, Sahai T N and Sharma S B 1997 The Precambrian Geology of the Aravalli Region, southern Rajasthan and northeastern Gujarat; Geol. Surv. India Memoir 123262 (with geological and structural maps on 1:253440 scale in 4 sheets each 1995).

Gutikrrez-Alonso G 1996 Strain partitioning in the footwall of the Somiedo Nappe: Structural evolution of the Narcea Tectonic Window, NW Spain; J. Struct. Geol. 18 1217-1229.

Heron A M 1953 Geology of Central Rajputana; Geol. Surv. India Memoir $\mathbf{7 9} 339$.

Herwegh M and Handy M R 1998 The origin of shape preferred orientations in mylonite: inferences from in-situ experiments on polycrystalline norcamphor; J. Struct. Geol. 20 681-694.

Passchier Cees W and Trouw Rudolph A J 2005 Microtectonics; 2nd edn, Springer, Germany.

Ramsay J G and Huber M I 1983 The techniques of modern structural geology, 1: Strain analysis; Academic Press, London.

Ree J H 1991 An experimental steady-state foliation; J. Struct. Geol. 13 1001-1011.

Sen S 1980 Precambrian stratigraphic sequence in a part of the Aravalli range, Rajasthan: A re-evaluation; Quart. J. Geol. Min. Metall. Soc. India 52(2) 67-76.

Sengupta S and Ghosh S K 2004 Analysis of transpressional deformation from geometrical evolution of mesoscopic structures from Phulad shear zone, Rajasthan, India; J. Struct. Geol. 26 1961-1976.

Sengupta S and Ghosh S K 2007 Origin of striping lineation and transposition of linear structures in shear zones; J. Struct. Geol. 29 273-287.

Simpson C and De Paor D G 1997 Practical analysis of general shear zones using the porphyroclast hyperbolic distribution method: An example from the Scandinavian Caledonides; In: Evolution of geological structures in micro- to macro-scales (ed.) Sengupta S, Chapman and Hall, pp. 169-184.

Singh K and Thakur V C 2001 Microstructures and strain variation across the footwall of the Main Central Thrust Zone, Garhwal Himalaya, India; J. Asian Earth Sci. 19 17-29.

Sinha-Roy S 1988 Proterozoic Wilson cycles in Rajasthan; Eol. Soc. India 7 95-107.

Sinha-Roy S, Mohanty M, Malhotra G, Sharma V P and Joshi D W 1993 Conglomarate horizons in south-central Rajasthan and their significance on Proterozoic stratigraphy and tectonics of the Aravalli and Delhi Fold Belts; J. Geol. Soc. India 41 331-350.

Sychanthavong S P H and Desai S D 1977 Protoplate tectonics controlling the Precambrian deformations and metallogenic epochs of NW peninsular India; Mineral. Sci. Eng. 9 218-237.

Tripathy N R, Srivastava H B and Mamtani M A 2009 Evaluation of a regional strain gradient in mylonitic quartzites from the footwall of the Main Central Thrust Zone (Garhwal Himalaya, India): Inferences from finite strain and AMS analyses; J. Asian Earth Sci. 34 26-37.

Vernon R H 2004 A practical guide to Rock Microstructure; Cambridge University Press, UK, 594p.

Wallis S R 1995 Vorticity analysis and recognition of ductile extension in the Sanbagawa belt, SW Japan; J. Struct. Geol. 17 1077-1093.

Weijermars R 1991 The role of stress in ductile deformation; J. Struct. Geol. 13 1061-1078.

Xypolias P 2010 Vorticity analysis in shear zones: A review of methods and applications; J. Struct. Geol. 32 2072-2092. 